取除く事が出来るようにした，更に，必要によっては压 迫固定す出来るようにした，撮影台は水平位上り垂直位 まで電動式にて可能である。 また, Aut-Changerも電動 式にて上下動が出来, 傾斜角を垂值よりマイナス 10 度ま で可能とさせ台車を取付けて移動出来るようにした，撮 影時には患者は前処置後, 水平位にて各固定具を装着し た後，撮影台を起し立体状態にして撮影を行う。

[結果]

造影剤と血液との不合和によって起きる悪現象をある 程度解消する事が出来た。

\section{9. 透視可能形連続撮影台}

日立レントゲン株式会社柏工場

○加藤 和昭・島 倭文郎・出来 文弘

長崎大学医学部附属病院

高尾 義人

\section{座長集約}

撮影 7 の演題群は血管造影に関する研究である．42番 は管球とSlitを造影剤の進行に同期し，造影剤を略均一 に充満，しかも濃度補正可能等の利点があるが駆動ムラ やSlit巾之管球装置容量等に問題がある，又Slitを被検 体の下だけでなく，上下に置いた場合も検討してみてほ しい.43番は内胸動脈に選択的に造影剂を注入する手技 で，従来より診断価值が向上するすのと思われる，44番 は脳血管の領域にも選択造影法を応用，一段之診断を有 利にしている，乙の場合両側前大脳動脈水平部と前交通 動脈の血行が充分あり, 造影剤量, 注入圧を適当に選ぶ 必要があるが興味深い術式である，45番は三種類の film changer を用い．画質の検討を行なっているが，各地で この種の装置は今後多用されるので, 新規購大する者の 為にす基礎的実験を続けてほしい，46番は既製の装犆を 改良し画質を向上させた報告だが，鬼角高度の研究のみ に走り，基礎実験がなおざりになる風潮があるので貴重 な傾向と思う。47番は関西大からむ追加発表があり, 雨 者の記録方式は異なるが生体信号を同一画面们同時記録 することは必要であり，今後の研究に期待したい，48番 は血管の全周を観察する方式として立位撮影台を考鉒， 好結果を得ている報告だが患者の固定には可成り問題が あり，より一層迅速且つ確実な方法をお願いする，49番 は透視台上であ連続撮影が可能な装置を開発害用化して いるが血管造影の如く迅速且つ確実性を要求される術式 には非常に有利である，以上简単に各演題を繹めてみた が血管造影手技，撮影タイミング，装置の選択等多くの 問題がある. 之等特殊撮影の研究は学会沈おいて発表す る以前に分科会等で演題を充分審議し，学会場では分科
会等で縓めたものを代表者が一括発表を行ない，質疑応 答の時間が充分もてるような運営をすべきではないかと 思う。

\section{撮 影 8 座長 遠山 坦彦}

\section{0. 胃部X線撮影に関する研究}

日本大学医学部附属板橋病院

○䴤沼 成美・松 浦 衙・池田正八郎 藤田 和男・杉浦ひろみ・田中 正義

[目的]

呼吸無停止撮影の考察，遠隔操作型 $\mathrm{X}$ 線テレビを使用 する際，術者対患者の呼吸停止のタイミングが合はずに 撮影の失敗を経験するととがある。そとで我々は上記目 的に沿ったものがどの程度の利用価值があるか否がつ いて検討した，胃の動きに対する診断能限界は，ファン トム,レリーフ像の肉眼観察によって行に併せてチャー 卜判別能によって基準を定めた，動き速度は動態撮影を 行い影像の最大傾きを求めた．その結果秒速 $25 \mathrm{~mm}$ 以内 であったのでしれを最大動き速度とした。一方，診断的 に許される粘膜像の動きは ext $0.1 \mathrm{sec} て ゙ ~ 0.8 \mathrm{~mm}$ 以内で あった，阔者の関係から求めた許容撮影時時間は $3 / 100$ 秒 以下であ机ば目的にかなった方法は可能である．現在， ルチン化を検討中である。

\section{質問}

現在，学会とは如何にあるべきか? 技術学とは何か という問題が学会本部で検討されています。その時ての 演題グループの中には，“技術学とは何加”というテーマ に対して疑問索感じさせる演題内容が数題含まれていま すので，大変失礼とは思いますが，あえて座長さんに， 今後の技術学の確立のために，その点での見解をうかが いたいと思います。

(福岡 吉武清秀)

\section{質問}

1）呼吸無停止撮影の条件は，撮影時間 0.03 秒以下之

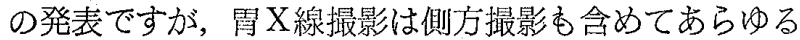
体位の撮影があり，しかす厚い被写体の人す撮影しなけ ればならない，そのような条件の中であらゆる人を，呼 且無停止撮影するととは，現在のX線装置では不可能で はないかと思う。三相全波整流装置に高速回転三極X線 管を組みこんで始めて可能となると思うが，如何でしょ うか。

2）私としては現状ではやはり四吸停止撮影がのぞま しいと思います。

（福岡 吉武清秀）

\section{答}

(1) 被写体の愿さが増加すると $(18 \mathrm{~cm})$ 以上になると 
現装置では余り有利でない

(2)呼吸無停止例の必要性は有．呼吸の停止出来ない 人や撮影を急ぐ場合はぜひ必要である.

51. 十二指腸検査のルーチン化について

香川県成人病センター放射線科 (指導 : 放射線科科長 坂下 修)

○木下 正司・福井 励子・高橋 和男 十二指腸の運動は，活発であるため，形態の著明な変 化を，X線像にとらえるととは，困難である，当セン夕 一に扑て，炤和 44 年 2 月より，十二指腸疾患発晃の向 上のため，検查方法を検討してきたが，現在ルチンとし て，次の方法で検査を行い，好成績を括さめている，胃 X線検查終了後, 蠕動を抑制し, 多量の空気を胃に送り 腹臥位とする．続いて右側を挙げるととにより，胃内の 空気を十二指腸へ移行させ, 腹卧位二重造影像を得る。 次いで左側臥位から背卧位とし, 背卧位二重造影像を得 る. 以上が検査法の概様である。

結果(1) X線撮影は，運動の位相を考えて，撮影時間 を決定する。

我々の経験では，0.06秒以内が好ましい.

（2）正面像よりは，斜位像が詮断上良好であった。

(3) 簡便でしかすゾンデ法に劣らないX線フィルムが 得られる。

（4）患者に与らる不安感とか, 不快感を軽減できた。 (ゾンデ法に比べ)

\section{質問}

ルーチンにファーター氏乳頭部を撮影する場合に被検 者によってマーゲン内のルフト量が違っているのにあか かわず，発泡散を一律に $5 \mathrm{~g}$ 服用させると云う事に疑問

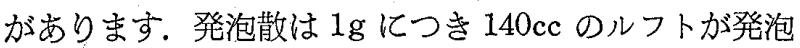
され30秒で消泡されます。発泡散を投入直後に飽用させ ると云う事は発泡ガス量を無だにしているのではないか. ゾンデでファーター氏乳頭部を撮影する場合は, $100 \mathrm{cc}$ のルフトが必要である．乙の点について演者はどの様に 考えておられますか. (広島山下和秀)

52. ペンタゾシン併用による点滴胆のう造影法の検討 （第 1 報）

静岡県立中央病院

○吉村 正己・松本 炤典・宮本 唯男 白鳥 岩男·西尾 孝次・四方，健一

[目的]

DIC法に総胆管末端収縮剤ペンタゾシンを加え（以下 DIC-P 法という) 肝内胆管及びファター氏膨大部の描 出改善を計り，造影写真による技術的面での検討を行っ
た。

[造影術式]

点滴終了直前にペンタゾシンを筋注し, $10 \cdot 30 \cdot 60$. 90 分, ヨーク投与後 $30 \cdot 60 \cdot 90$ 分に撮影を行い正常群. 疾患群につき肝内胆管の径 - 長さ, 総胆管末端出現率等 検討した。

[結論]

（1） DIC-P法の基本撮影法は，10·30.60分，ヨーク 後60分でよい.

（2）DIC-P 法では，DIC 法に較べ, 肝内胆管, 総胆 管末端の出現率后上が見られた。

\section{質問}

胆管末端部まで描出させるためには，撮影条件，特に 管電圧の影響が大きいよ思われます，どのような撮影条 件をとられましたか, 参考まで御教示ください。

（関西 英加豆士男）

答

FFD $110 \mathrm{~cm}$,ブッキー $12: 1$, 腹厚 $18 \mathrm{~cm} 83 \mathrm{kVp} 200$ $\mathrm{mA} 1.0 \mathrm{sec}$ (第 2 斜位) (立) $18 \mathrm{~cm} 98 \mathrm{kVp} 200 \mathrm{~mA} 0.4 \mathrm{sec}$ 肝内胆管の撮影条件については，10分後の写真におい て, 適正濃度をチェックし, 条件の補正を行っている。 30分，60分についても同様である.

\section{3. 胆のう造影撮影条件の検討（第 1 報）}

北九州市立戸畑病院

○藏，和夫・高根 重信

園下，善継・益田 伸子

水ファントームに高さ $6 \mathrm{~cm}$ の位置に模擬胆のうとし てゴム風船を固定, 造影剤はビリグラフィンを使用し, 6 種類の㓌性胆石についてその適正電圧及び胆のう検査 時の骨㖪及び生殖腺被曝量を求めた，水 $20 \mathrm{cc}$ と胆石を入 れ，造影剤を $10 ， 15 ， 20 \mathrm{cc}$ 順次加えて，各造影剂濃度 での胆石, 胆のうとアルミカイルを 50 〜 $100 \mathrm{kVp}$ まで 10 $\mathrm{kVp}$ どとに撮影してフィルム特性曲線より胆のう, 胆石 の黒化度とコントラストの変化を比較した。線量測定は ヒューマンファントームに小型電離槽を挿入して標準被 曝線量を測定したものに，X線出力と半価尿を測定し被 曝線量を求めた。

6 種類の胆石の黒化度の有意差はなく，黒化度は80 $\mathrm{kVp}$ で，コントラストは $70 \mathrm{kVp}$ で極大となる，被曝線量 は高電圧ほど減少し， $60 \mathrm{kVp}$ と $90 \mathrm{kVp}$ の比ではほぼ1/10と なる。

䁲問

Ganad dose が電玨が上昇するに従って，減少する， これは一般の考え方とは違っていると思いますが？ 